DOI: $10.2478 /$ v10028-009-0003-1

\title{
VEGETATION OF THE ŽALE CEMETERY (LJUBLJANA)
}

\author{
Urban ŠILC ${ }^{1}$
}

\begin{abstract}
The paper presents results of a vegetation survey of the cemetery of Ljubljana as a specific urban habitat with a high diversity of vegetation types. Seventeen different plant communities were found, mostly weed (hoe weed and garden communities), trampled and ruderal communities. This indicates frequently disturbed habitat with different microclimatic conditions than those in the surroundings.
\end{abstract}

Key words: synathropic vegetation, plant sociology, urban habitat, Slovenia.

\section{Izvleček}

Članek predstavlja rezultate proučevanja vegetacije ljubljanskega pokopališča, ki je poseben urbani habitat $\mathrm{z}$ veliko diverziteto vegetacijskih tipov. Našli smo sedemnajst različnih rastlinskih združb, večinoma plevelnih (okopavinskih in vrtnih), pohojenih in ruderalnih sintaksonov. To nakazuje rastišče s pogostimi motnjami z drugačnimi mikroklimatskimi razmerami kot v okolici.

Ključne besede: sinantropna vegetacija, fitosociologija, urbani habitat, Slovenija.

\section{INTRODUCTION}

The cemetery is special habitat in the frame of urban environment. Therefore we could treat the cemetery as an ecosystem characterized by its history, structure and function, including both biotic and abiotic components (cf. Sukopp 2002). This reflects in many different ways: intensity and frequency of anthropogenic disturbances, heterogeneity of sites, introduction of alien species, higher temperature and lower humidity. Consequently this is visible in specific species composition of vegetation.

Systematic research of the vegetation of cemeteries is rare, usually flora were studied, while vegetation was sampled only sporadically. Generally only ornamental plants were collected, spontaneous flora has been an object of research for the last 25 years (Sukopp 2002). A survey of ecological studies of cemeteries was made by Graf (1986), a larger study after that was done also by Pyšek (1988).
Flora of the cemetery of Žale in Ljubljana was published by Babij (1998).

\section{RESEARCH AREA}

The researched area comprises the main cemetery of Ljubljana (Žale) (Figure 1), that spreads over approx. 26 ha and is sourrounded by a 2 metre-high wall. The climate is mildly warm and perhumid, average temperature is $9.7^{\circ} \mathrm{C}$ and precipitation $1400 \mathrm{~mm}$. The microclimate is probably modified by reduced extremes (Babij 1998), although higher temperatures could be expected due to the openness of the space and to the asphalt and stone material used. A particularity of cemeteries are soils with strong human influence (according to WRB- World Reference Base for Soil Resources). The first group are Technosols whose properties and pedogenesis are dominated by their technical origin. They are sealed by technic hard rock (material created by humans,

\footnotetext{
${ }^{1}$ Institute of Biology, Scientific Research Centre of the Slovenian Academy of Sciences and Arts, Novi trg 2, SI-Ljubljana, urban(a)zrc-sazu.si.
} 
having properties unlike natural rock) - here we refer to pavements with their underlying unconsolidated materials. A smaller part is covered by Anthrosols, a soil type where cultivation is practised (this could be classified as Hortisols- garden soil) (WRB). A special subtype for cemeteries was introduced as necrosol (Graf 1986).

\section{METHODS}

Vegetation was sampled according to the standard Central European method (Braun-Blanquet 1964, Westhoff \& van der Maarel 1973). Phytosociological nomenclature is according to Jarolímek et al. (1997), nomenclature of mosses follows

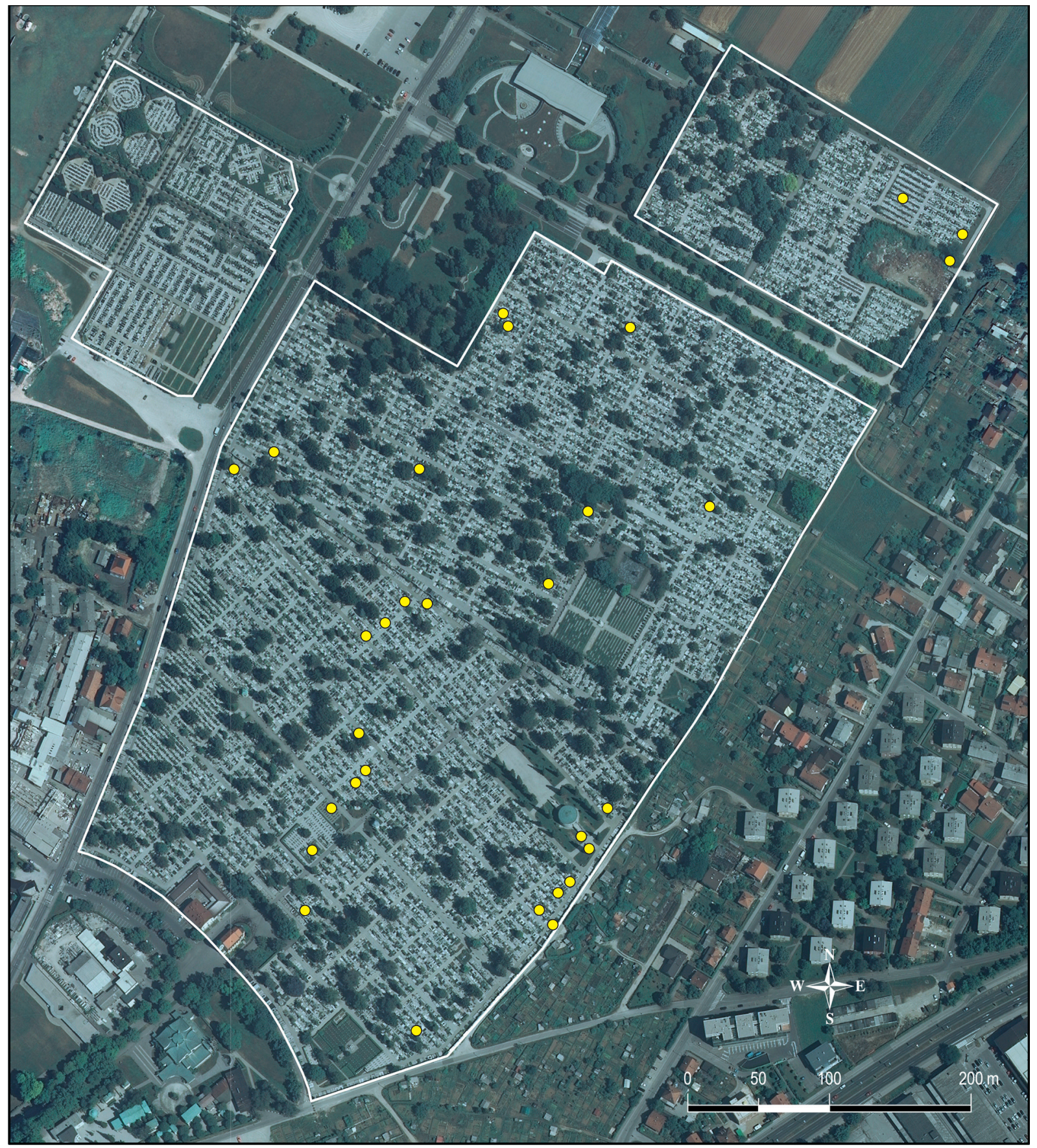

Figure 1: Researched cemetery.

Slika 1: Raziskovano pokopališče. 
Martinčič (2003) and of plants Martinčič et al. (2007), except for species Eschscholtzia californica Cham.

\section{RESULTS AND DISCUSSION}

Syntaxonomical scheme of researched syntaxa presented in Table 1:

Asplenietea trichomanis (Br.-Bl. in Meier et Br.-Bl. 1934) Oberd. 1977

Tortulo-Cymbalarietalia Segal 1969

Cymbalario-Asplenion Segal 1969 em. Mucina 1993

Asplenietum ruta-murariae-trichomanis Kuhn 1937 - relevé 1

Cymbalarietum muralis Görs in Oberd. 1967 - relevés $2-3$

Polygono arenastri-Poetea annuae Rivas-Martínez 1975 corr. Rivas-Martínez et al. 1991

Polygono arenastri-Poetalia annuae $\mathrm{R}$. Tx. in Géhu et al.

Saginion procumbentis $\mathrm{R}$. Tx. et Ohba in Géhu et al. 1972

Sagino procumbentis-Bryetum argentei Diemont et al. 1940 - relevé 4

Herniarietum glabrae (Hohenester 1960) Jehlík et Hejný 1975 - relevé 5

Stellarietea mediae R. Tx., Lohm. et Preising in R. Tx. ex von Rochow 1951

Centaureetalia cyani $\mathrm{R}$. Tx., Lohmeyer et Preising in R. Tx. ex von Rochow 1951

Veronico-Euphorbion Sissingh ex Passarge 1964

Mercurialietum annuae Kruseman et Vlieger 1939 - relevés 6-10

Sherardion arvensis Kropáč et Hejný in Kropáč 1978

Aethuso-Galeopsietum G. Müller 1964 - re-

levé 11

Atriplici-Chenopodietalia albi R. Tx. (1937)

Nordhagen 1940

Panico-Setarion Sissingh in Westhoff et al. 1946

Echinochloo-Setarietum pumilae Felföldy

1942 corr. Mucina 1993 - relevé 12

Sisymbrietalia J. Tx. in Lohm. et al. 1962

Sisymbrion officinalis R. Tx., Lohm. et Preising in $\mathrm{R}$. Tx

Erigeronto-Lactucetum serriolae Lohm. in
Oberd. 1957 em. Mucina 1978 - relevé 13

Eragrostietalia J. Tx. ex Poli 1966

Eragrostion R. Tx. ex Oberd. 1954

Portulacetum oleraceae Felföldy 1942 - relevé 14

Salsolion ruthenicae Philippi 1971

Panicetum capillaris Mititelu et Roman 1988 - relevés 15-17

Eragrostio-Polygonion arenastri Couderc et Izco ex Carni et Mucina 1997

Eragrostio-Polygonetum arenastri Oberd. 1954 corr. Mucina 1993 - relevé 18

Portulaco-Euphorbietum maculatae (Brandes 1993) Čarni et Mucina 1998- relevés 19-22

Chamaesyco humifusae-Oxalidetum corniculatae Forstner in Mucina 1993- relevés $23-25$

Artemisietea vulgaris Lohmeyer, Preising et R. Tx. ex von Rochow 1951

Onopordetalia Br.-Bl. et R. Tx. ex Klika et Hadač 1944

Dauco-Melilotion Görs 1966

Dauco-Picridetum Görs 1966- relevé 26

Odontio-Ambrosietum artemisiifoliae Jaro-

límek et al. 1997- relevés 27-29

Equisetum arvense-[Onopordetalia] - relevé 30

Galio-Urticetea Passarge ex Kopecký 1969

Lamio albi-Chenopodietalia boni-henrici Kopecký 1969

Galio-Alliarion (Oberd. 1957) Lohmeyer et Oberd. in Oberd. et al. 1967

Impatiens parviflora-[Galio-Alliarion] - relevé 31

Communities of the alliance Cymbalario-Asplenion thrive on walls or at their foot. Stands where Asplenium trichomanes dominates are found on dry, sunny walls, while the association Cymbalarietum muralis is found on more shaded and nitrate rich sites.

Trampled habitats are frequent in the cemetery, but moist and nutrient poor communities that are classified into the alliance Saginion procumbentis are not so frequent as more thermophilous trampled communities. The association Sagino-Bryetum is characterized by moss Bryum argenteum and prostrate Sagina procumbens, that are found as a mosaic between shaded paving stones. Hernarietum glabrae thrives on drier and sandy ground than the previous community 
and is a monodominant community of Herniaria glabra.

Most frequent communities found in the cemetery are mostly annual segetal and ruderal communities classified into the class Stellarietea medi$a e$. This is consistent as there is strong anthropogeneous pressure, considering hoeing, planting of ornamental plants and weeding (on the path also mechanically).

The association Mercurialietum annuae is monodominant, extremly thermophilous and is usually found on sand on graves, where there are better, nutrient rich soils. The Aethuso-Galeopsietum has not yet been described in Slovenia. On the cemetery it is only fragmetarily developed, characterised by diagnostic species Aethusa cynapium, Medicago lupulina and Galeopsis tetrahit (sensu Mucina 1993). Holzner (1973) mentions occurrence of the community on permeable, sandy, skeletal soils. The association Echinochloo-Setarietum pumilae is one of the most widespread associations of segetal communities, but is only fragmentarily developed on the cemetery and is dominated by $\mathrm{C}_{4}$ grasses.

The association Erigeronto-Lactucetum comprises stands of biannual weeds and represents a transition between syntaxa of annual and perennial weeds. Species composition depends on the time since the last disturbance (cultivation, weeding). As disturbances are extremely frequent and intensive in the cemetery there are found numerous species of the class Stellarietea mediae.

The association Portulacetum oleraceae thrives on the cultivated part of the grave (planted by ornamental flowers), where the soil is fertile. Optimum development of the community is in the late summer.

Panicetum capillaris is a typical railroad plant community. A similar warm and dry habitat on sand is found in the cemetery. Dominant species Panicum capillare is regularly accompanied by $\mathrm{Se}$ taria viridis. For Slovenia the association has not been yet recorded.

Into the alliance Eragrostio-Polygonion arenastri we classify communities of trampled habitats, and it is characterized by $\mathrm{C}_{4}$ species (Mucina 1993).

Eragrostio-Polygonetum is the central association of the alliance without any character species. The association Portulaco-Euphorbietum maculatae is characterized by the neophyte species Euphorbia maculata that dominates in the stands and by Arenaria serpyllifolia as differental species (Brandes 1993). The association Chamaesyco humifusae-Oxalidetum corniculatae is recorded for the first time for Slovenia. It is indicated by dominant species Euphorbia humifusa and Oxalis corniculata and is an extremely warm community on trampled sites (sand and paved paths).

Dauco-Picridetum develops on abandoned graves, but it is rare. Ambrosia artemisiifolia dominated communities are on the expansion in Slovenia (it expands from ruderal to cultivated sites), but it is only fragmentarily developed in the cemetery; above all species of the class Artemisietea are missing. The community of species Equisetum arvense is frequent; similar stands are also found on the railroads. We classify it only to the level of the association according to Mucina (1993).

Communities of the class Galio-Urticetea are rare as the habitat is too warm and dry. Impatiens parviflora dominated stands thrive on shaded sites.

The vegetation of cemeteries is specific due to the uniqueness of the environment. It is extremly thermophilous, disturbances are frequent and intensive. Therefore communities of the class Stellarietea mediae prevail, thus hoe weed communities as thermophilous communities of trampled soil. Most communities are fragmentarily developed (less character species, above all of higher syntaxa) and are poor in species number.

Compared to the syntaxa list from Central and North European cemeteries (Graf 1986, Pyšek 1988), in our case Galio-Urticetea communities are lacking, indicating a more warm and dry habitat although this could be also explained by history, cemetery type and land use.

\section{REFERENGES}

Babij, V. 1998: Flora ljubljanskih Žal. Scopolia 39: 1-39.

Brandes, D. 1993: Eisenbahnanlagen als Untersuchungsgegenstand der Geobotanik. Tuexenia 13: 415-444.

Braun-Blanquet, J. 1964: Pflanzensoziologie. Grundzüge der Vegetationskunde. Springer Verlag, Wien, 865 pp.

Graf, A. 1986: Flora und Vegetation der Friedhöfe in Berlin (West). Verhandlungen des Berliner Botanischen Vereins 5: 1-210.

Holzner, W.,1973: Ackerunkrautvegetation Niederösterreichs. Mitt. bot. Arb. gem. Oberoesterr. 5 (1): 1-157. 
Jarolímek, I., Zaliberová, M., Mucina, L., Mochnacký, S. 1997: Rastlinné spoločenstvá Slovenska, 2. Synantropná vegetacia. Bratislava: Veda vydavatelstvo slovenskej akadémie vied, Bratislava, 416 pp.

Martinčič, A. 2003: Seznam listnatih mahov (Bryopsida) Slovenije. Hacquetia 2 (1): 91-166.

Martinčič, A., Wraber, T., Jogan, N., Podobnik, A., Ravnik, V., Turk, B., Vreš, B., Frajman, B., Strgulc-Krajšek, S., Trčak, B., Bačič, T., Fischer, M. A., Eler, K. \& Surina, B. 2007: Mala flora Slovenije: ključ za določanje praprotnic in semenk. Tehniška založba Slovenije, Ljubljana, 845 pp.

Mucina, L., Grabherr, G. \& Ellmauer, T. 1993: Die Pflanzengesellschaften Österreichs. Anthropogene Vegetation. Gustav Fisher Verlag, Jena, $578 \mathrm{pp}$.

Pyšek, P. 1988: Floristisch - und Vegetationsverhältnisse des Zentralen Friedhofs in der Stadt Plzeň. Folia Musei rerum naturalium Bohemiae occidentalis 25: 1-46.

Sukopp, H. 2002: On the early history of urban ecology in Europe. Preslia 74 (4): 373-393.

Westhoff, V. \& Van Der Maarel, E. 1978: The Braun-Blanquet approach. In: Whittaker, R. H. (eds.): Ordination and Classification of Communities. Dr. W. Junk Publishers, The Hague, 617-727 pp.

World reference base for soil resources 2006, Food and Agriculture Organization of the United Nations, Rome, 2006, World Soil Resources Report 103, 128 p.

\section{APPENDIX (date, location, coordinates)}

1. 9.8.2006, Ljubljana: Žale, staircase of ossuary of I. WW, wall, 102910, 464247; 2. 5.9.2006, Ljubljana: Žale, grave Slapšakovi, rocky tombstone, 102848, 464227; 3. 9.8.2006, Ljubljana: Žale, wall of monument of Salesians of Don Bosco, 102900, 464057; 4. 9.8.2006, Ljubljana: Žale, paved path between paving stones, shaded under pine and spruce in front of grave Dekvalovi, heavily trampled, 102983, 464090; 5. 5.9.2006, Ljubljana: Žale, grave Borčič, near entrance to the cemetery of Italian soldiers, paved, trampled, 103089, 464224; 6. 2.9.2008, Ljubljana: Žale, grave Kocmur, sandy path between graves, shaded, 103076, 464123; 7. 2.9.2008, Ljubljana: Žale, graves Krainer Viktor, sand in front of grave, shaded, 103140, 464252; 8. 2.9.2008, Ljubljana: Žale, Erženovi
(Eržen Franko), on the grave, sand, of ossuary of I. WW, 102930, 464266; 9. 5.9.2006, Ljubljana: Žale, grave of Gorup, sand, 102858, 464218; 10. 9.8.2006, Ljubljana: Žale, grave of family Vozelj, sand, 103271, 464196; 11. 9.8.2006, Ljubljana: Žale, grave of family Trapetovi, sand, 103170, 464133; 12. 5.9.2006, Ljubljana: Žale, grave Klembas, sand, 102773, 464131; 13. 5.9.2006, Ljubljana: Žale, grave Požlep, in front of ossuary of I. WW, sand, 102901, 464253; 14. 9.8.2006, Ljubljana: Žale, grave of family Šprohar, fertile garden soil, 103280, 464192; 15. 9.8.2006, Ljubljana: Žale, near vault Wagner, behind vault Kollman, sandy path, 102948, 464088; 16. 5.9.2006, Ljubljana: Žale, grave Hažič Alojz, sand, path between graves, less trampled, 102901, 464253; 17. 5.9.2006, Ljubljana: Žale, grave Purič, sandy path in front of the grave, poorly trampled, 103144, 464338; 18. 2.9.2008, Ljubljana: Žale, paved footpath, partly shaded, 103075, 464139; 19. 9.8.2006, Ljubljana: Žale, paved main road, 103170, 464002; 20. 9.8.2006, Ljubljana: Žale, near grave of family Šilc, sandy path, 102858, 464052; 21. 9.8.2006, Ljubljana: Žale, paved path, near grave Orehek, 103061, 464109; 22. 9.8.2006, Ljubljana: Žale, near monk's grave, at vault Kollman, paved path, 102930, 464071; 23. 5.9.2006, Ljubljana: Žale, grave Leon Šporšič, path between graves, shaded, trampled, 102878, 464239; 24. 2.9.2008, Ljubljana: Žale, grave Koštomaj Gabrijela, footpath, paved, sunny, 103052, 464095; 25. 2.9.2008, Ljubljana: Žale, opposite to grave Jakša Frančiška, abandoned grave, better sandy soil, 103361, 464475; 26. 9.8.2006, Ljubljana: Žale, end of cemetery of Žale, sand between graves Kačičnik and Štajdohar, 103336, 464517; 27. 5.9.2006, Ljubljana: Žale, grave of family Logar, grave, 102870, 464231; 28. 9.8.2006, Ljubljana: Žale, near sign 23, sandy path, 102957, 464095; 29. 5.9.2006, Ljubljana: Žale, grave of family Adamič, sand on the grave, 103182, 464030; 30. 2.9.2008, Ljubljana: Žale, grave Gmeiner Josipina, sandy footpath, 103270, 464282; 31. 9.8.2006, Ljubljana: Žale, near rubbish dump on the new part of Žale, 103317, 464508. 
Table 1: Phytosociological table of vegetation of the cemetery Žale (Ljubljana).

Tabela 1: Fitocenološka tabela vegetacije pokopališča Žale (Ljubljana).

\begin{tabular}{|c|c|c|c|c|c|c|c|c|c|c|c|c|c|c|c|c|c|c|c|c|c|c|c|c|c|c|c|c|}
\hline Releve number & 1 & 2 & 3 & 4 & 5 & 6 & 7 & 8 & 11 & $\begin{array}{lll}0 & 11\end{array}$ & $11 \quad 12$ & 213 & 14 & 15 & 16 & 171 & 1819 & 1920 & 021 & 222 & 2324 & 425 & 262 & 272 & 282 & 293 & 303 & 31 \\
\hline Relevé area $\left(\mathrm{m}^{2}\right)$ & 4 & 2 & 2 & 5 & 4 & 2 & 3 & 3 & 3 & 3 & 2 & 5 & 2 & 3 & 3 & 1 & 2 & 2 & 5 & 5 & 0,5 & 2 & 10 & 2 & 3 & & & 3 \\
\hline Altitude (m) & 297 & 2972 & 2972 & 2972 & 2972 & 2972 & & & 9729 & 9729 & 97297 & 7297 & 2972 & 2972 & 2972 & 2972 & 29729 & 9729 & 7297 & 2972 & 297297 & 97297 & 2972 & 2972 & 2972 & 29729 & 2972 & 297 \\
\hline Aspect (degrees) & NE I & NW & $\mathrm{S}$ & - & - & - & - & - & - & & - & - & - & - & - & - & - & - & - & - & - & - & - & - & - & - & - & - \\
\hline Slope (degrees) & 90 & 90 & 90 & - & - & - & - & - & - & - & - & - & - & - & - & - & - & - & - & - & - & - & - & - & - & - & - & - \\
\hline Cover herb layer $(\%)$ & 40 & 207 & 702 & 203 & 30 & 40 & 807 & 707 & 705 & 507 & $70 \quad 40$ & 80 & 70 & 80 & 809 & 903 & 3050 & $50 \quad 50$ & 30 & 808 & $80 \quad 30$ & $0 \quad 50$ & 1008 & 80 & & 1008 & 801 & 100 \\
\hline Cover moss layer (\%) & 2 & 2 & 1 & 25 & 50 & 0 & 0 & 0 & 0 & 0 & 0 & 0 & 0 & 0 & 0 & 0 & 0 & 0 & 0 & 0 & 0 & 0 & 0 & 0 & 0 & 0 & 0 & 0 \\
\hline Number of species & 4 & 5 & 4 & 8 & 9 & 8 & 7 & 7 & 77 & $7 \quad 1$ & 118 & 10 & 6 & 8 & 111 & 14 & $9 \quad 10$ & $10 \quad 6$ & 8 & 13 & 9 & 7 & 11 & 7 & 141 & 105 & 5 & 6 \\
\hline
\end{tabular}

Character and differential species of the associations

\begin{tabular}{|c|c|c|c|c|c|c|c|c|c|c|c|c|c|c|c|c|c|c|c|c|c|c|c|c|c|c|c|c|c|c|c|}
\hline Asplenium trichomanes & $\mathrm{C}$ & 3 & 1 & $\cdot$ & v & - & · & . & . & - & . & . & - & - & . & . & . & . & . & $\cdot$ & . & & . & - & & . & & . & . & - & . \\
\hline Cymbalaria muralis & & . & 2 & 4 & $\cdot$ & ${ }^{\circ}$ & . & $\cdot$ & . & . & 1 & . & . & . & . & . & . & . & - & . & . & - & & . & & r. & & ${ }^{\circ}$ & . & . & . \\
\hline Asplenium ruta-muraria & & . & + & . & . & . & . & . & . & . & . & . & . & . & . & . & . & . & . & . & · & . & 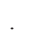 & . & · & 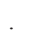 & & . & . & . & . \\
\hline Tortula muralis & $\mathrm{D}$ & + & . & + & . & . & . & . & . & . & . & . & . & . & . & . & . & . & . & . & 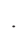 & . & . & . & . & . & - & . & . & . & . \\
\hline Sagina procumbens & $\mathrm{C}$ & . & . & . & 2 & & . & . & . & . & . & . & . & . & . & 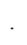 & . & . & . & . & & . & . & . & 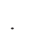 & . & & . & . & . & . \\
\hline Bryum argenteum & $\mathrm{D}$ & . & . & . & 1 & 2 & . & . & . & . & . & . & . & . & . & . & . & . & . & + & & . & & . & & & & . & . & . & . \\
\hline Herniaria glabra & $\mathrm{C}$ & . & . & . & . & 2 & . & . & . & . & . & . & . & . & . & . & . & . & . & + & 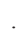 & . & . & . & & & & . & . & . & . \\
\hline Mercurialis annua & & . & . & . & . & . & 3 & 4 & 3 & 3 & 2 & . & . & . & . & $\cdot$ & . & . & . & . & . & . & . & + & . & . & $\cdot$ & . & . & . & . \\
\hline Aethusa cynapium & & . & . & . & . & . & . & . & . & $\cdot$ & . & 3 & . & . & . & . & . & . & . & + & ${ }^{\circ}$ & . & . & . & . & . & . & . & . & . & . \\
\hline Galeopsis tetrahit & & . & . & . & . & . & . & . & . & . & . & + & . & . & . & . & . & . & . & . & . & . & . & . & . & . & . & . & . & 1 & . \\
\hline Lactuca serriola & & . & . & . & . & . & + & . & . & . & . & . & . & 3 & . & + & . & . & . & . & . & . & . & . & . & . & . & . & . & . & . \\
\hline Portulaca oleracea & & . & . & . & . & . & . & . & . & . & . & . & . & . & 3 & $\cdot$ & . & . & . & . & . & . & . & . & . & . & . & . & . & . & . \\
\hline Panicum capillare & & . & . & . & . & . & . & . & . & . & . & . & . & . & . & 4 & 4 & 4 & . & . & . & . & . & . & . & . & . & . & + & . & . \\
\hline Eragrostis minor & & . & . & . & . & . & . & . & . & . & . & . & . & . & . & . & . & . & 2 & 1 & . & 1 & 1 & . & . & . & . & . & . & . & . \\
\hline Euphorbia maculata & & . & . & . & . & . & . & . & . & . & . & . & . & . & 1 & . & . & . & + & 3 & 3 & 3 & 3 & . & . & . & . & . & . & . & $\cdot$ \\
\hline Euphorbia humifusa & & . & . & . & . & 1 & . & . & . & . & . & . & + & . & . & . & . & . & . & . & . & . & . & 2 & 1 & 1 & . & . & . & . & . \\
\hline Oxalis corniculata & & . & . & . & . & 1 & . & . & . & . & . & . & . & . & . & . & . & . & . & . & . & . & . & 3 & + & 2 & . & . & . & . & . \\
\hline Daucus carota & & . & . & . & . & . & . & . & . & . & . & . & . & . & . & . & . & . & . & . & . & . & . & . & . & . & 3 & . & . & . & . \\
\hline Picris hieracioides & & . & . & . & . & . & . & . & . & . & . & $\cdot$ & . & . & $\cdot$ & . & . & . & . & . & . & . & . & . & . & . & 2 & . & . & . & . \\
\hline Ambrosia artemisiifolia & & . & . & . & . & . & . & . & . & . & . & ${ }^{\circ}$ & . & . & . & . & . & . & . & . & . & . & . & . & . & . & . & 4 & 3 & 5 & . \\
\hline Equisetum arvense & & . & . & . & . & . & . & . & . & . & . & . & . & . & . & . & . & . & . & . & . & . & . & . & . & . & . & . & . & . & 3 \\
\hline Impatiens parviflora & & . & . & . & $\cdot$ & . & . & + & . & . & . & . & $\cdot$ & . & $\cdot$ & . & . & $\cdot$ & . & . & $\cdot$ & . &. & . & . & . & . & 2 & . & . & . \\
\hline
\end{tabular}

\section{Polygono-Poetea}

Plantago major

Polygonum aviculare agg.

Poa аппиа

Stellarietea mediae

Setaria viridis

Digitaria sanguinalis

Oxalis fontana

Sonchus oleraceus

Anagallis arvensis

Fallopia convolvulus

Cerastium glomeratum

Eschscholtzia californica

Euphorbia peplus

Chenopodium album

Diplotaxis muralis

Stellaria media

Sonchus arvensis 
Releve number

$\begin{array}{lllllllllllllllllllllllllllllll}1 & 2 & 3 & 4 & 5 & 6 & 7 & 8 & 9 & 10 & 11 & 12 & 13 & 14 & 15 & 16 & 17 & 18 & 19 & 20 & 21 & 22 & 23 & 24 & 25 & 26 & 27 & 28 & 29 & 30 & 31\end{array}$

\section{Artemisietea}

Silene vulgaris

Erigeron annuus

Convolvulus arvensis

Conyza canadensis

Linaria vulgaris

Elytrigia repens

\section{Galio-Urticetea}

Calystegia sepium

Lapsana communis

Glechoma hederacea

Rubus caesius

Molinio-Arrhenatheretea

Medicago lupulina

Taraxacum officinale

Trifolium pratense

Vicia cracca

Pastinaca sativa

Leontodon autumnalis

Plantago lanceolata

Achillea millefolium

Festuca rubra agg.

Poa pratensis

Trifolium repens

Potentilla reptans

Dactylis glomerata

Ranunculus repens

Rumex obtusifolius

\section{Other taxa}

Microrrhinum minus

Viola reichenbachiana

Arenaria serpyllifolia

Sedum sexangulare

Bryum sp.

Didymodon vinealis

Hedera helix

Homalothecium sericeum

Pimpinella saxifraga

Acer pseudoplatanus

Pimpinella anisum

Leontodon sp.

Silene sp.

Mahonia aquifolium

Hypericum perforatum

Verbascum nigrum
C

$+.1 .2+.1 \% 1$

$\mathrm{C}$

$\mathrm{C}$

. . . . . . $+.+1.4+$

$+\cdot 1$ 